\title{
Beck Sinar
}

University of York

DOI: http://dx.doi.org/10.5617/adno.5605

\section{Promoting metalinguistic awareness in a classroom to improve reading comprehension: Examples from Roald Dahl's novel The BFG}

\begin{abstract}
It is widely recognised that successful reading involves the interaction of a number of different cognitive skills and strategies in order to achieve comprehension of the text (Baker, 2002). These skills and strategies are generally considered to be controlled by a global process called 'metacognition' (Kuhn \& Dean, 2004). In this paper, I suggest that a large part of metacognition when reading has a (meta)linguistic component and hence time should be devoted to raising (meta)linguistic awareness when teaching and honing reading skills and strategies.

Tasks based around a short extract from Roald Dahl's (1982[2013]) novel The BFG are presented and discussed in order to illustrate how metalinguistic awareness might be raised in a classroom. Such tasks not only help to improve reading comprehension but have a number of additional benefits: they enhance and support the metacognitive toolkit, improve vocabulary acquisition and growth, and can bring a love of language and the fun of language play into the classroom.
\end{abstract}

Keywords: metalinguistic awareness, reading comprehension, vocabulary, classroom activities, Roald Dahl

\section{Å fremme metalingvistisk bevissthet i et klasserom for å forbedre leseforståelse: eksempler fra Roald Dahls roman The BFG}

\section{Sammendrag}

Det er bred enighet om at vellykket lesing trekker veksler på flere forskjellige kognitive ferdigheter og strategier tilknyttet tekstforståelse (Baker, 2002). Disse ferdighetene og strategiene hører inn under den globale prosessen 'metakognisjon' (Kuhn \& Dean, 2004). I denne artikkelen argumenterer jeg for at en stor del av metakognisjonen i lesing har en (meta)lingvistisk komponent, og følgelig 
at tid bør vies til å utvikle (meta)lingvistisk bevissthet $i$ undervisningen av leseferdigheter og strategier.

Arbeidsoppaver basert på et kort utdrag fra Roald Dahls (1982[2013]) The BFG (The Big Friendly Giant / SVK - Store Vennlige Kjempe) presenteres og diskuteres for å illustrere hvordan metalingvistisk bevissthet kan utvikles $i$ klasserommet. Slike arbeidsoppgaver hjelper ikke bare med å forbedre leseforståelsen, men har også flere andre fordeler: de forsterker og støtter den metakognitive verktøykassen, forbedrer både innlæring og utvidelse av ordforrådet, kan øke språkgleden og oppmuntre til lek med språk i klasserommet.

Nøkkelord: metalingvistisk bevissthet, leseforståelse, vokabular, klasseromsaktiviteter, Roald Dahl

\section{Introduction}

Metacognition is a global process that allows individuals to be able to monitor and control their thinking and learning (Anderson, 2002, p. 1; Kuhn \& Dean, 2004; Lai, 2011, p. 2; Martinez, 2006; Wilson \& Conyers, 2016, p. 8). It was first introduced into the field of education and literacy by Flavell (1979) and applied to reading by Brown (1980). Metacognition has two main parts (Hogan, Dwyer, Harney, Noone, \& Conway, 2015, p. 75; Schraw, Crippen, \& Hartley, 2006):

(i) being aware of cognitive strategies and processes, i.e. what we know

(ii) being able to choose and apply suitable cognitive strategies to achieve the desired outcome (when, where and how to use strategies, i.e. what we can do)

Despite decades of research into which cognitive strategies and processes are used when reading, there is little consensus over exactly which are used, when each is used and the type and nature of the relationships which exist between them, leading Perfetti and Stafura (2014, p. 22) to claim: "There is no theory of reading, because reading has too many components for a single theory". However, it is clear that a major component of reading involves language and knowledge about that language, i.e. awareness of linguistics and metalinguistics, which are the focus of this paper. It is widely acknowledged that there is a relationship between metacognition and metalinguistics (see Grabe, 2009; Koda, 2007; Kuo \& Anderson, 2008; Nagy, 2007; Yuill, 1996), with most researchers suggesting that the latter is subordinate to the former, with a structure along the lines shown in Figure 1, where I have highlighted the role of metalinguistics. 


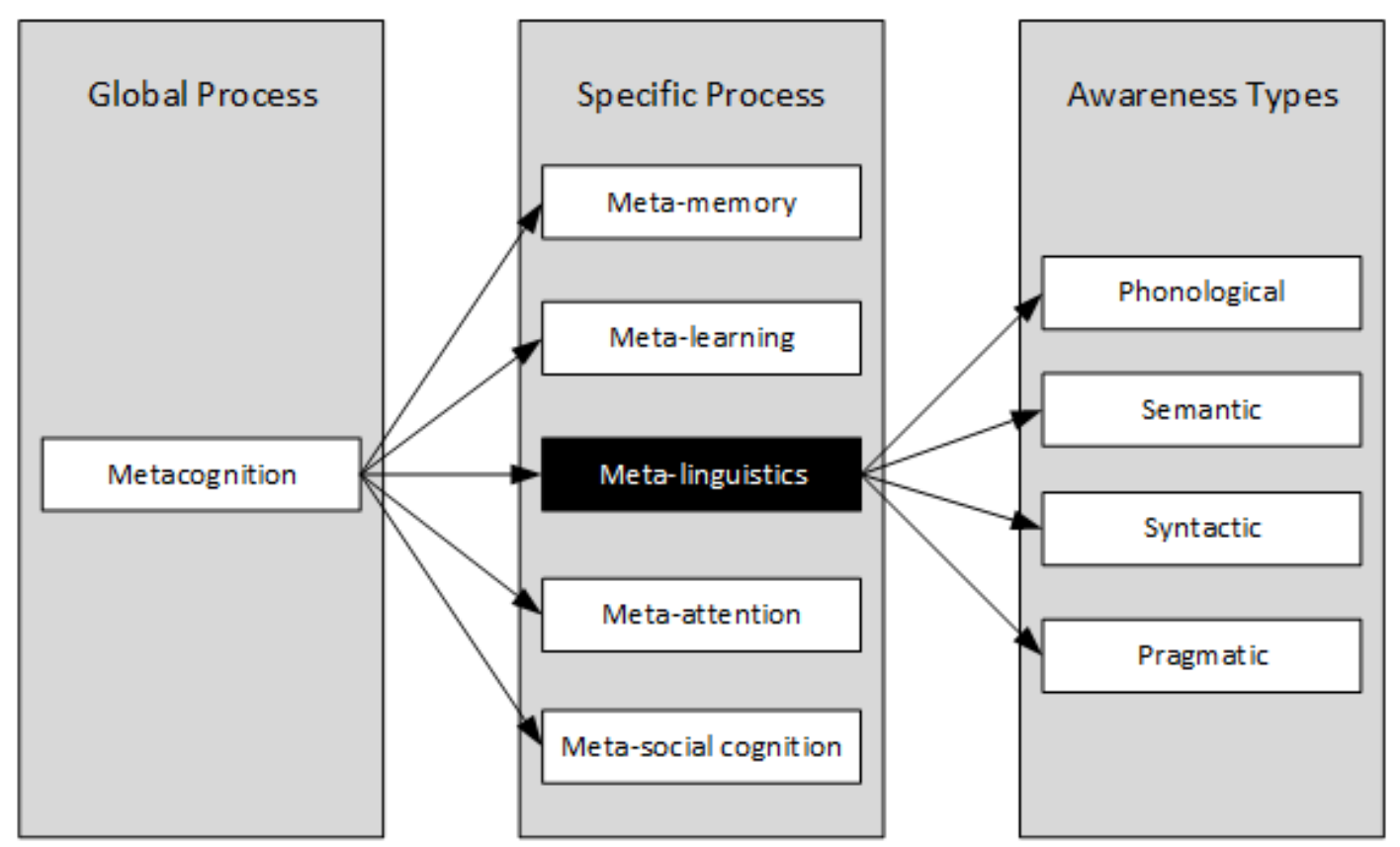

Figure 1. The Relationships between Metacognition and Metalinguistics, based on Tunmer, Pratt and Herriman (1984).

The exact relationship between metacognition and metalinguistics is uncertain, and more theoretical discussion is required to consider questions such as whether metalinguistics is completely subordinate to metacognition and in which way(s), and/or whether or not the relationship between the two is bidirectional and, if so, in what respects. The answers to these questions fall well outside the scope of this single paper, taking in issues in developmental psychology and the acquisition of language as well as philosophical questions about the constructs of meaning and the nature of the mind. However, as far as we understand the relationship thus far, it seems clear that promotion of metalinguistic awareness would be a beneficial and important aspect of an individual's metacognitive toolkit. Therefore, this paper considers how promotion of metalinguistic awareness in a classroom might be beneficial to readers, and provides examples of what teachers might do in order to develop and promote this awareness. In the first half of this paper, I consider questions of a theoretical nature:

1. What are the linguistic strategies and skills used in reading?

2. What is metalinguistic awareness and how does it relate to reading?

In the second part of the paper, I demonstrate how aspects of these theories can be brought into the classroom via discussion of a number of tasks based around Roald Dahl's fictional text The BFG (1982[2013]), which is an initialism for 'The Big Friendly Giant'. In doing so, I seek to answer the following questions:

3. What are some of the potential benefits of metalinguistic knowledge and awareness for readers?

4. How can metalinguistic awareness be promoted in a classroom? 


\section{Background: Theoretical Framework for Reading}

Reading is a complex process; it involves a number of different strategies and skills working together (Baker, 2002; Chambers, 2011, p. 60; Grabe, 2009, p. 14). Readers start with strategies which require conscious effort, and when these become automated they are considered to be skills (Paris, Wasik, \& Turner, 1991; Williams \& Atkins, 2009, p. 26).

Evidence suggests that successful and proficient readers are strategic and orchestrate the use of cognitive strategies and/or skills such as being aware of what they are reading, being motivated and knowing why they are reading, and having a set of strategies for dealing with potential problems (Cromley \& Azevedo, 2007; Magliano \& Millis, 2011, p. 132; Pressley \& Afflerbach, 1995; Pressley \& Gaskins, 2006, p. 100). Some examples of cognitive strategies/skills when reading include:

- Use of typographical aids to help identify key information

- Use of tables, figures, illustrations to help understanding

- Using existing knowledge

- Making predictions / asking questions

- Using context clues

A major role of metacognition regarding reading is in monitoring comprehension in order to ensure that it occurs and to seek repair in cases where it fails (see e.g. Baker, 2002; Pressley, 2002). Strategies for repair might be, for example, to re-read a word, sentence or passage, use any pictures or illustrations, or to adjust reading speed to a slower pace. Other metacognitive processes involved in reading are inferencing, goal setting and revising, and responding to difficult texts strategically. This means readers asking themselves questions like:

- What is the author's intention?

- Do I understand?

- Are my inferences about the text correct?

- How do I respond to difficulties in the text?

- What are my goals?
= inferencing

$=$ monitoring comprehension

$=$ monitoring accuracy

$=$ responding strategically

= goal setting

However, much of reading is linguistic; it is about processing and decoding information about language (Perfetti, Landi, \& Oakhill, 2005). Hence, in addition to the skills and strategies discussed above, any model of reading should consider (at least) phonological and orthographical awareness and decoding, word identification, meaning retrieval (semantics), sentence parsing (syntax) and text structure (genre, pragmatics).

One such model is known as the 'simple model of reading' (Gough \& Tunmer, 1986; Hoover \& Gough, 1990). Such models take a bottom-up approach to reading (word-based) and propose that there are essentially two strands 
involved: decoding and linguistic comprehension (see, e.g. Gough, Hoover, \& Peterson, 1996, and Joshi \& Aaron, 2000, for more recent adaptations of this model). Under such models, early readers must first learn to consciously decode that graphemes (letters) correspond to phonemes (sounds) before then recognising that phonemes combine to form morphemes (words). Morphemes carry meaning (semantics) and it is at this point that the second aspect of the simple reading model - comprehension - is required. Readers need to be able to recognise the connection between the form of the word and its meaning.

In addition, more advanced readers would want to recognise the connotations of the words and pay attention to their particular usage, including style (informal or formal), collocations (the way words occur together), and consider if words are used figuratively (take on meanings beyond the most usual ones, as is the case with similes, metaphors and idioms). Words combine to form sentences following rules of syntax (grammar / word order). Word order also affects meaning; it allows the reader to ascertain information such as who did what to whom, i.e. what is the subject and what is the object of the sentence.

Learners may have deficits in decoding, comprehension or both (see e.g. Vellutino, Fletcher, Snowling, \& Scanlon, 2004) which provides evidence for these two aspects of such models. However, it is likely that other factors are involved, such as environment and psychological factors, and hence this model is too simple (Adlof, Catts, \& Little, 2006; Berninger, Dunn, Lin, \& Shimada, 2004; Høien-Tengesdal, 2010; Quigley, 2018; Verhoeven \& Snow, 2001). Further, a purely bottom-up approach to reading fails to take into account topdown (knowledge-driven) approaches (Beard, 1987, p. 24), the connections between the two approaches, and the likelihood that readers employ a variety of strategies (top-down and bottom-up) when reading (Naylor \& Wood, 2012, p. 37; Skaftun, 2011). Stafura and Perfetti (2017), building on work in Perfetti (1999) and subsequent studies, attempt to arrive at a wide-angle framework of reading systems taking in both top-down and bottom-up approaches, as shown in Figure 2.

This framework shows an overview of the relationships between the complex factors involved in reading, whilst also allowing the possibility for researchers to focus on individual aspects of the framework in order to provide more detailed models and empirical testing, whilst still having the framework to provide the more global picture often lacking. Hence, it seems to me to be a good starting point for discussion and empirical work. 


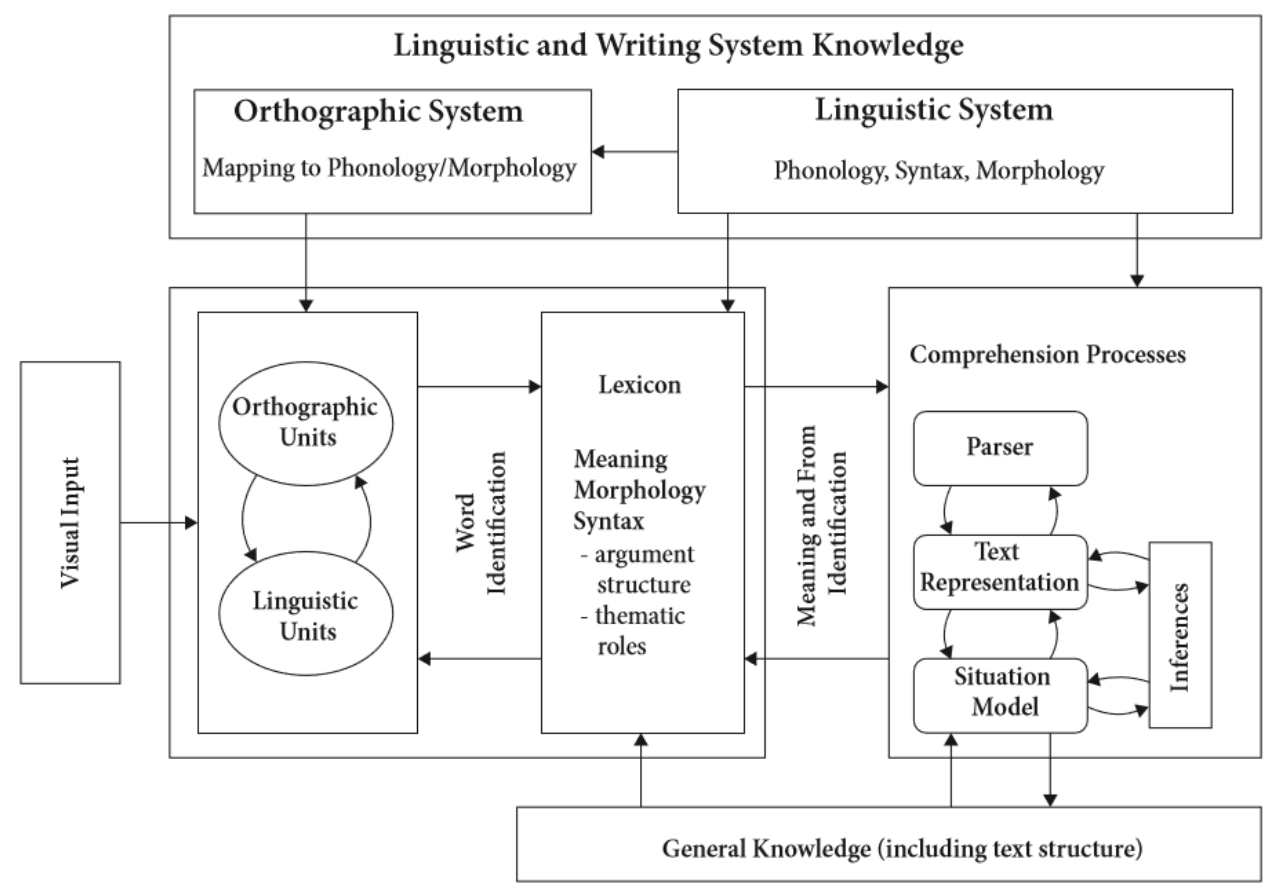

Figure 2. Reading Systems Framework (Stafura \& Perfetti, 2017, p. 11, based on Perfetti, 1999). [In the vertical text in the middle of the figure, "Meaning and From" should read "Meaning and Form".]

There has been a fair amount of empirical testing and discussion of the role of the orthographic (written) system and how it maps to phonological skills and awareness of them as a precursor for - or as part of - the development of early reading skills (early readers: DeVries, 2015, pp.73-97; Elbro, 1996; Høien \& Lundberg, 2000; Lundberg, 2002, 2009; later readers: Zipke, 2007, 2011). In comparison, the role of the lexicon seems to have been a somewhat neglected component, and hence it is this aspect which will be the focus of the second half of the paper. As I am dealing with information at the word-level, I take a broadly bottom-up approach and try to demonstrate how attention at the word level filters up towards the top where aspects such as enjoyment and context play a significant role.

The lexicon seems to sit in the centre of the framework shown in Figure 2, between the phonological and orthographical mapping, and decoding and comprehension. It seems likely therefore that the lexicon is a kind of critical "pinch point" for reading and that the higher the quality of the information in the lexicon and the control that the reader has of that information, the more successful the reader is likely to be (see for example, the discussion in Quigley, 2018, regarding the effects of a 'vocabulary gap'). This is known as the lexical quality hypothesis, first postulated by Perfetti and Hart (2002) (see also Perfetti, 2007; Stafura \& Perfetti, 2017).

In conclusion, theories of reading should acknowledge the involvement of a number of linguistic skills, which in turn interact with other cognitive skills, including memory. This means that to be successful, readers must over time develop aspects of what Nagy (2007) calls the metalinguistic hypothesis. This 
means that they should become aware of their linguistic knowledge and skills and be able to monitor and control them (Koda, 2008; Kuo \& Anderson, 2008; Tunmer, Herriman, \& Nesdale, 1988). There are several aspects to this which are illustrated in the list below with respect to reading:

- Phonological or phonemic awareness - this needs to link to orthographical awareness so that readers are able to decode words on a page

- Syntactic awareness - how word order affects meaning, recognising syntactic categories for new words, using syntactic information as contextual information, disambiguating lexical meanings

- Semantic awareness - understanding that words vary in meaning, building new definitions, both of which would aid in comprehending a text

- Morphological awareness - realisation that words are made up of meaningful constituent parts which could aid a reader in word retrieval from memory or in establishing a meaning for a new word

In the next section, I illustrate how this might be achieved in a classroom.

\section{Method and Results: The 'Metalinguistic Giant' in the Classroom}

Teachers promote metacognitive awareness in a classroom in a number of ways; asking students to paraphrase or summarise texts, retell stories, engage in readers' theatre, take a storyline approach or engage in "text talk" (see e.g. ideas in Ahlquist \& Lugossy, 2014; Chambers, 2011; Ingemansson, 2017; Tarrant \& Holt, 2016).

In addition, teachers may use tasks in the classroom which develop metalinguistic awareness: this is the background behind teaching phonics for early literacy, and also the seemingly short 'throw-away' tasks for more advanced readers/learners which involve exercises such as the categorisation of words into parts of speech (nouns, verbs, adjectives, etc.), finding synonyms and so on. However, far from being 'throw away', such tasks awaken metalinguistic awareness. In the following discussion, Roald Dahl's The BFG (1982[2013]) is used to illustrate the value of the 'metalinguistic giant' in a classroom. Similar tasks could be applied to different texts, different genres, to readers at different levels and in both L1 and L2 classrooms, as the principles and ideas expressed are universal to reading: but the exact skills and strategies practised and used would, of course, vary. Whilst I use a small extract here, the tasks could be extended to larger extracts or whole works. I begin by providing background on Dahl and the chosen novel, before discussing how it could be used in a classroom. I then report on a small-scale pilot study conducted with L1 English speakers aged eight or nine which sought to ascertain some empirical backing for the methods proposed in this section. 


\section{Background on Dahl and The BFG}

Dahl has been popular in the UK for over 30 years (see: Chilton, 2012; Hall \& Coles, 1999; Topping, 2010). Topping (2017) surveyed nearly 850,000 children in primary and secondary schools in the UK to find out about their reading habits. Roald Dahl was the fourth most popular author, and maintained this position in 2016. (This was, however, a decline on the second position he obtained in 2015). The most popular author was Jeff Kinney, with David Walliams and Roderick Hunt rising in popularity and taking second and third place respectively. Dahl proved particularly popular with children between the ages of 8 and 13, getting at least two books into the top ten books for each age group. This is due in part to the popularity of the books in UK schools and amongst teachers, but there is also evidence from, for example longstanding library borrowing figures (Campon, 2013) and sales figures (BBC, 2016), that Dahl is read outside school for pleasure. There is growing evidence for the importance and value of reading for pleasure for educational purposes as well as personal development (Clark \& Rumbold, 2006; Holden, 2004) and for the importance of reading fiction for those obtaining high world-wide literacy scores (UK Department for Education, 2012).

There is a wealth of agreement that using authentic materials in an L2 classroom is beneficial (Birketveit \& Williams, 2013) and that using strategies which work in L1 can also work in L2 (Drew, 2017). Whilst Dahl's popularity outside the UK may be less than within it, sales figures and the number of translations of his work, as well as recent global film releases, suggest that his works are still well received. In a simple survey of 83 teachers of English from Norway (grades 1-10) attending short courses at the Norwegian Study Centre, University of York, in January and February 2018, 55\% (N=46) said they had used some Dahl in their English teaching, with the percentage rising to $73 \%$ (N= 61) when asked if they had used Dahl in English and/or Norwegian. Mostly they had used Charlie and the Chocolate Factory, Matilda and/or the Witches with students in grades 5-9 (ages 10-15).

The BFG (1982[2013]) was one of Dahl's favourite stories and charts the unlikely friendship of a young orphan girl, Sophie, and the BFG, and their adventures in Giant Country and London, in which they seek to overcome a group of man-eating giants. The story presents a major challenge to its readers as it makes use of a number of humorous neologisms (new words) which Dahl invents in order to delight and entertain his readers as well as to enhance the other-worldliness of his theme: that this is a story of giants (and humans). Whilst we are most likely to find such neologisms in fiction, they are also frequently found in written media texts, like newspapers and blogs, as well as in speech. The strategies which neologisms allow readers to focus upon (see further below), are also useful in dealing with any unfamiliar word, including in expository or non-fiction texts. 
In using these neologisms, collectively known in the case of Dahl's works as gobblefunk, Dahl is arguably working in the well-established "nonsense language" tradition of British children's literature which dates back at least to Edward Lear and Lewis Carroll (see Andersen, 1950; Malcolm, 1997; Stewart, 1979; Tigges, 1988 for further details of this tradition). Learners will already have some familiarity with this tradition through British nursery rhymes encountered early in their schooling, but the vocabulary will be new to all. Gobblefunk words therefore present comprehension challenges of the kinds discussed in Koda (2007) and Kuo and Anderson (2006) and hence represent a good opportunity for metacognitive and metalinguistic development and discussion in a classroom as will be illustrated below. In particular, gobblefunk presents a good opportunity for readers to be learners and practise and develop strategies for coping with gaps in word knowledge which might otherwise cause comprehension failure. This is in keeping with the idea that it is good to give students texts which require planful strategies, not just automated skills (Cromley \& Azevedo, 2007; Ericsson \& Simon, 1993).

\section{The Extract and the possible results in a Classroom}

The following is an extract from Chapter 8 "Snozzcumbers" (Dahl, 1982[2013], p. 42). There are a number of challenging words in this extract as shown in italics, some of which will be discussed below.

"Here is the repulsant snozzcumber!" cried the BFG, waving it about. "I squoggle it! I mispise it! I dispunge it! But because I is refusing to gobble up human beans like the other giants, I must spend my life guzzling up icky-poo snozzcumbers instead. If I don't, I will be nothing but skin and groans."

Upon being presented with Chapter 8, readers are immediately challenged by its title: snozzcumbers. Since this is not a text aimed at either children beginning to read or beginning to learn English, it is most likely that the challenge will not be one of phonological decoding and that most will arrive at a pronunciation of /snbzkımbə/. The problem is that this is a word created for this text and hence it cannot simply be retrieved from the mental lexicon. The metacognitively aware reader will firstly decide whether or not attention and resources need to be devoted to establishing the meaning of this word and if so, will make a guess (inference) about the meaning of this word using one or more of the strategies listed below. The most successful readers will likely be the ones with the ability to utilise the most strategies, and to continually monitor and review their inferences in the light of further evidence as they continue to read (Pressley \& Afflerbach, 1995; Pressley \& Gaskins, 2006). 
- Use any nearby illustrations. Upon seeing Quentin Blake's illustrations in this chapter, the reader might guess that it is some kind of large, knobbly, striped fruit or vegetable.

- Make a guess based upon their understanding of the text to that point.

- Skim read ahead to see if a definition is presented or if further information is given.

In addition, the reader will rely upon using (meta)linguistic knowledge:

- Phonological: it comprises lots of suspiciously sibilant sounds: /s/ and /z/ and based on sound symbolism (phonaesthesia) a reader might guess that this is a word which has negative connotations.

- Syntactical: it occurs as a word on its own to name a chapter $=$ most likely a noun.

- Morphological: it ends in an <-s> so is possibly a count noun = a name of something.

- Lexical: it appears to be a blend of snozz+cumber. Relying on memory / existing word-knowledge, a reader might infer that cumber is from cucumber and that snozz is something related to the nose as it is similar to the word snot (in fact it is likely Dahl used US slang schnozz 'nose', 'nostril'). If the reader has come across blends or portmanteau words previously, they might know that these words take some of their meaning from both words and hence they could hypothesise that this is a kind of smelly and/or slimy fruit. In fact, tasks involved in making and identifying blends are quick for a teacher to make and often bring fun and enjoyment with language into a classroom. Some simple illustrative tasks of this nature are provided in Figure 3. Completing such tasks raises awareness of how words are formed and how meaning is established in such contexts, making it more likely that a reader might be able to recognise them in future texts. Furthermore, it seems likely that such awareness also feeds into the way children use words in their own writing. The relationship between good reading and good writing is discussed in, for example, Blair (2013).

A small scale pilot study of 10 eight- and nine-year old girls with L1 English, was conducted in order to test the effectiveness of the tasks in Figure 3. Following the exercises, the girls completed a short survey in which they were asked to evaluate the tasks. They reported that they "liked trying to crack the code", "found it fun to play with words" and "I feel more confident that I know what the strange words mean because I can work them out". When presented a week later with a different, previously unseen passage from The BFG, the girls were all able to identify several new blends, explain how they were made, and make accurate inferences about the meanings of those words. The next stage will be to try to provide further and more robust empirical backing for the effectiveness of these kinds of tasks with learners in the UK and Scandinavia. 


\section{Task 1}

Some examples of blended words from Roald Dahl have been provided in the following table. In pairs, talk about what you think the meaning of each neologism might be. What did you do to guess the meaning?

\begin{tabular}{|l|l|l|l|l|}
\hline Word 1 & + & Word 2 & $=$ & Neologism \\
\hline Horrible & + & Disgust & $=$ & Horrigust \\
\hline Wiggly & + & English & $=$ & Wigglish \\
\hline Disgusting & + & Dangerous & $=$ & Disgusterous \\
\hline
\end{tabular}

Task 2

Below are some words formed via blending from recent UK newspapers. Can you:

(1) work out which two words have been blended together to make the neologism and fill in the blanks in the table below?

(2) guess what the meaning of the neologism might be? Which parts of meaning are kept and which parts are lost for each of the two words used in the blend?

\begin{tabular}{|l|l|l|l|l|l|}
\hline Neologism & $=$ & Word 1 & + & Word 2 & Meaning \\
\hline Jeggings & $=$ & Jeans & + & leggings & $\begin{array}{l}\text { Tight trousers which look like jeans but } \\
\text { don't have any pockets }\end{array}$ \\
\hline Irritainment & $=$ & & + & & \\
\hline Smiggle & $=$ & & + & & \\
\hline
\end{tabular}

Task 3

Can you make up your own blended words to share with others in the class?

\begin{tabular}{|l|l|l|l|l|}
\hline Word 1 & + & Word 2 & $=$ & Neologism \\
\hline Zebra & + & Elephant & $=$ & Zebphant \\
\hline & & & & \\
\hline & & & & \\
\hline
\end{tabular}

Figure 3. Example tasks to promote creating and understanding blended words.

All of the strategies discussed above can be modelled and practised in the classroom with the right kind of scaffolding. For example, with the given extract, students can be asked to read and underline any words which they think Dahl created. This encourages readers to monitor their reading and recognise potential problems for comprehension, without the pressure or embarrassment of acknowledging that they do not know the words and/or their meanings. Any number of follow-up tasks to this underlining task can encourage readers to then devote further resources to them. For example:

(1) Can the reader divide unfamiliar/new words into different parts of speech?

Knowing the part of speech helps us to work out where a word fits into a sentence, which can help to begin to establish meaning. Strategic readers might use morphological and/or syntactic clues to help to work out the part of speech. For morphology: certain affixes are used more frequently with certain categories of words, and for syntax readers can look at where a word occurs in a sentence and also what other words it occurs with. For example, a student might not know the words gobble (up) or guzzling (up) even though these are not some of Dahl's 
gobblefunk words and they exist in the Oxford English Dictionary. Readers with some training/practice in being metalinguistically aware might, however, be able to recognise that these words are both verbs since gobble occurs after an infinitival to and guzzling ends in an <-ing> which is often (but not always) a verbal suffix. Further, both words seem to take an object [human beans] and [icky poo snozzcumbers]. Finally, guzzling occurs between the subject and object, making it most likely a verb on the basis of English sentence structures and hence some kind of action (in this case, both are verbs which refer to eating).

(2) Can the reader use existing linguistic knowledge to guess some or all of the meaning of the words?

\section{Morphology}

Consider the words mispise and dispunge. The prefix $<$ mis- $>$ is originally a Germanic prefix with the main meaning of 'amiss, wrong(ly), or bad(ly)', and it is found in words like mistake, miscount and misspell. < dis-> is originally a Latin prefix which is now found in many English words. The main function of this prefix is to signal that something goes in the opposite direction (it reverses something), e.g. discomfort, discontent, discontinue, disarm, disrobe. Since $<$ dis-> reverses something it is often associated with words which have a negative connotation, which is also true for $\langle$ mis- $>$. On the basis of this information, a reader could therefore hypothesise that mispise and dispunge are not positive words. Building on this, lesson plans in "The BFG Phizzwizzing Lesson Plans” (2017) and "The BFG Lesson Plans” (2018) suggest that readers/learners fill in a worksheet guessing whether words have positive or negative meanings. This can be further adapted so that more advanced learners fill in a sheet which also divides words up not only via broad meaning, but also via part of speech.

There is evidence that this kind of morphological training/awareness helps with reading comprehension, particularly in relation to establishing meaning of unknown words (Brinchmann, Hjetland, \& Lyster, 2016; Cunningham \& Carroll, 2013; Deacon \& Kirby, 2004; Lee, 2011; Lyster, Lervåg, \& Hulme, 2016) and that it is also linked to reading ability (Carlisle, 2000; Kirby, Deacon, Bowers, Izenberg, Wade-Woolley, \& Parrila, 2012; Nunes \& Bryant, 2007; Singson, Mahony, \& Mann, 2000). The link between morphology and meaning (semantics) is shown diagrammatically in Figure 4. English morphology should, however, always be used with caution due to its irregular nature (compare casual and casualty) and hence readers must always be strategic and flexible in their use of potential sources of information about words. 


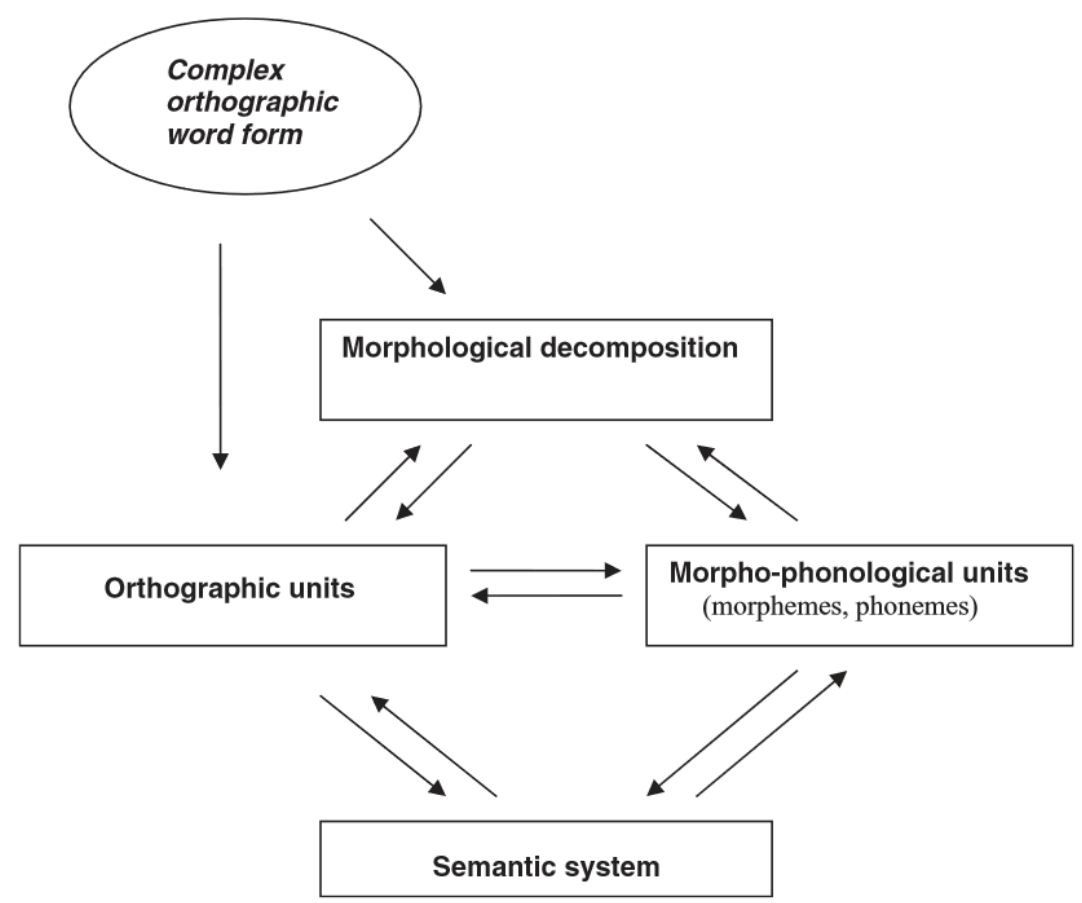

Figure 4. The role of morphology in the identification of complex words (Verhoeven \& Perfetti, 2011, p. 458)

\section{Existing vocabulary}

Whilst now obsolete, the word dispunge is found in the Oxford English Dictionary with two meanings: (1) to wipe out, blot out, delete and (2) to discharge or pour down as from a squeezed sponge. The latter is used by Shakespeare and is etymologically made up of the Latin prefix dis and the verb sponge meaning to wipe or rub with a wet sponge.

A reader might already know the noun sponge and be able to recognise that in this word it is used as a verb given its position in the sentence which follows the most usual SVO order of English:

$\begin{array}{lll}\text { I } & \text { dispunge } & \text { it } \\ \text { Subject } & \text { Verb } & \text { Object }\end{array}$

However, it seems more likely that Dahl intended to exchange prefixes from one negative one to a different negative one. Under this reading, dispunge is likely a play on the word expunge which has a closer meaning to sense (1). Expunge comes from the prefix <ex-> meaning 'out' and Latin pungěre 'to prick' and has the modern meaning of to 'strike out, blot out, erase, omit or even to destroy or put an end to'. Swapping prefixes certainly explains mispise; a change of prefix from $<$ de- $>$ in despise to an alternative with a similar meaning $<$ mis- $>$.

Hence, we can see from these examples that readers who have greater knowledge of affixes would, in theory, be able to perform better in wordrecognition and reading comprehension, evidence for which has been provided in previous studies (Carlisle, 2000, 2003; Cunningham, Perry, \& Stanovich, 
2001; Deacon \& Kirby, 2004; Singson, Mahony, \& Mann, 2000). Recent research indicates that this is true for L2 learners of English as well as L1 learners (Ginsberg, Honda, \& O’Neil, 2011; Kuo \& Anderson, 2006; Ramirez, Chen, Geva, \& Kiefer, 2010).

In sum, to assign meaning to these two words, the metalinguistically aware reader can make use of:

- Knowledge of word formation and how this affects meaning by applying information about prefixes. Many words can be worked out on the basis of their component parts.

- Existing knowledge of words such as despise, sponge, expunge. In using existing knowledge, we might suppose that linguistics interacts with cognition (unless we subscribe to the idea that language is stored and used from a separate part of the brain).

- Syntactic knowledge to recognise that these words are transitive verbs and hence part of an action performed by the subject (in these cases the pronoun $I$ ) to the object (in these cases the pronoun it). By using further syntactic knowledge the reader can ascertain that $I=$ The BFG and $i t=$ the snozzcumber.

To support this metalinguistic awareness, a reader might also make use of contextual information as an additional level of information (Perfetti, 1994, 1999; Perfetti \& Hart, 2001). It is clear from the fact that the BFG is crying and waving the snozzcumber about that he is emotional, and with other words like icky-poo and repulsant close by the most likely inference is that the BFG is in some way unhappy.

(3) Do words have other possible meanings?

One of the challenges when reading is that words can have multiple meanings (polysemy) and that words can sometimes sound the same but be spelled differently (homonyms). This is also a challenge during vocabulary acquisition (e.g. see Cameron, 2001; Redman, 1997; Schmitt, 2000; Thornbury, 2002). Authors, such as Dahl, make use of this with language play. The metacognitively aware reader might consider the purpose of the author in using such language: often it is for the sake of comparison or humorous or dramatic effect. Therefore, studying language play can bring fun and humour into the classroom as well as promote metalinguistic awareness and hence metacognitive awareness.

In the provided extract, with human beans Dahl plays on the near homophony of two words: being (UK /'bi:m/ and U.S. /'biry/) versus bean (UK /bi:n/ U.S. /bin/). The humour here lies in the fact that this is about eating and beans are something which can be eaten whilst being expresses that something exists.

In the case of the malapropism, skin and groans, Dahl presents an opportunity for readers/learners to think of words which sound similar to each other: here groans is misused in place of the similar sounding noun bones. 
Figurative language, such as malapropisms, but also idioms, spoonerisms, similes, metaphors, hyperbole and personification involve a word or phrase which does not have its normal, everyday, literal meaning, meaning it can be tricky to comprehend.

\section{Discussion}

The provided extract provides a dramatic example of the metalinguistic giant in action because of the large amount of the unfamiliar, but the same strategies and skills can be practised with different texts at different stages in a learner's/ reader's life. To support metalinguistic awareness, a teacher therefore might use a passage such as the one presented and ask learners/readers to perform seemingly simple tasks:

- Underline/identify difficult words.

- Think about other known words which are similar to the difficult words.

- Break the words down to try to recognise bits of morphology / identify word formation techniques. Elsewhere in the BFG, there are opportunities to look at other word formation techniques such as reduplication ucky-mucky, infixation scrumdiddlyuptious, spoonerisms catasterous disastrophe, compounding butcherboy, and the effects of alliteration maidmasher.

- Work out the part of speech.

- Consider whether there are other possible meanings of that word.

- Ask readers to think about phonaesthesia. This can be done via tasks such as those in "Using the BFG in the Classroom" (2017) where students are asked to divide sounds into glorious sounds and terrible sounds and explain their thinking.

Research provides evidence of a connection for improved reading comprehension as metalinguistic awareness develops (Cain, 2007; Kuo \& Anderson, 2006; Nagy, Berninger, \& Abbott, 2006; Tong, Deacon, Kirby, Cain, \& Parrila, 2011; Zipke, 2007, 2011; Zipke, Ehri, \& Cairns, 2009), but there is scope for further research in this direction, particularly in L2 English settings or with languages other than English.

In addition, focus on the language in this fashion will help with wordrecognition skills and vocabulary growth (Berninger, Abbott, Nagy, \& Carlisle, 2010; Bowers \& Kirby, 2010; Brinchmann, Hjetland, \& Lyster, 2016; DeVries, 2015; Nagy, 2007; Wagner, Muse, \& Tannenbaum, 2007). This reciprocal relationship between reading comprehension and the knowledge and acquisition of vocabulary has been recognised in L1 contexts by, for example, Carver (2003) and Wagner, Muse and Tannenbaum (2007), and in L2 contexts by, for example, Laufer (1997) and Verhoeven (2000). Other researchers have shown other effects, including on spelling accuracy (Lee, 2011; Nunes, Bryant, \& 
Bindman, 2006), with second language learning (Birketveit \& Rimmereide, 2012), and that learning the orthographic features of morphemes may also support the development of decoding abilities (Carlisle \& Goodwin, 2013).

\section{Conclusion}

Metalinguistic awareness is like a big friendly giant. It includes increased awareness of phonemes, syllables, and rhymes, of meaning-bearing morphemes, words, and phrases, of syntax, and of denotations, connotations, and lexical ambiguities, of homonyms, synonyms, and antonyms, of slang, dialect, and jargon, of academic language and figurative devices like metaphor, idioms, and hyperbole, and more. Awareness of all these things helps to ensure comprehension when reading, and provides the reader with options for repair or for making predictions and inferences when comprehension breaks down or is not fully realised. For example, when a reader encounters a new word, they are able to rely on morphological knowledge and awareness in order to attempt to establish meaning by breaking a word down into different morphemes (Brinchman, Hjetland, \& Lyster, 2015).

There can be little doubt that raising metalinguistic awareness also feeds and develops a crucial part of a reader's metacognitive reading strategy toolbox (O’Malley \& Chamot, 1990; Oxford, 1993) since there is a link between metalinguistics and metacognition (Koda, 2007) and much of reading concerns linguistic knowledge and skills (Nagy, 2007; Perfetti, 1999). Whilst further empirical evidence is required in English L1 and L2 contexts, as well as in languages other than English, it would seem that effective teaching practices should make use of instruction which promotes metalinguistic awareness as part of a metacognitive toolkit to help with word recognition, vocabulary growth and perhaps most importantly, as The BFG helps us, to get (borrowing from $B F G$ ), "kicksy" comprehension.

\section{About the author}

Dr. Beck Sinar is a lecturer at The Norwegian Study Centre, University of York. Her research interests include the socio-cultural history of the English languages and literatures, inter-cultural communication and education, and didactics.

Institutional affiliation: The Norwegian Study Centre, Quantum House, University of York, Heslington, York, YO10 5DD, UK.

E-mail: beck.sinar@york.ac.uk 


\section{References}

Adlof, S. M., Catts, H. W., \& Little, T. D. (2006). Should the simple view of reading include a fluency component? Reading and Writing, 19, 933-958.

Ahlquist, S., \& Lugossy, R. (2014). Stories and storyline [ebook]. Candlin and Mynard epublishers.

Andersen, J. (1950). Edward Lear and the origin of nonsense. English Studies, 31, 161-166.

Anderson, N. J. (2002). The role of metacognition in second language teaching and learning. ERIC Digest: Education Resources Information Centre.

Baker, L. (2002). Metacognition in comprehension instruction. In C. Block \& M. Pressley (Eds.), Comprehension instruction: research-based best practises (pp. 77-95). New York: Guilford Press.

BBC (2016). Roald Dahl: As popular - and profitable - as ever. http://www.bbc.co.uk/programmes/p04521p2

Beard, R. (1987). Developing Reading 3-13. Oxford: Hodder and Stoughton.

Berninger, V. W., Abbott, R. D., Nagy, W., \& Carlisle, J. (2010). Growth in phonological, orthographic, and morphological awareness in grades 1 to 6. Journal of Psycholinguistic Research, 39, 141-163.

Berninger, V., Dunn, A., Lin, S., \& Shimada, S. (2004) School evolution: Scientist Practitioner educators creating optimal learning environments for ALL students. Journal of Learning Disabilities, 37, 500-508.

Birketveit, A., \& Rimmereide, H. E. (2012). Does reading stories enhance language learning? In A. Hasslegren, I. Drew, \& B. Sørheim (Eds.), The young language learner: research based insights into teaching and learning. Bergen: Fagbokforlaget.

Birketveit, A., \& Williams, G. (2013). Introduction. In A. Birketveit \& G. Williams (Eds.), Literature for the English classroom: theory into practise (pp. 7-14). Bergen: Fagbokforlaget.

Blair, B. (2013). Reading and writing: intertwined branches. In A. Birketveit \& G. Williams (Eds.), Literature for the English classroom: theory into practise (pp. 235-254). Bergen: Fagbokforlaget.

Bowers, P. N., \& Kirby, J. R. (2010) Effects of morphological instruction on vocabulary acquisition. Reading and Writing: An interdisciplinary Journal, 23 (5), 515-537. doi: https://doi.org/10.1007/s11145-009-9172-z

Brinchmann, E. I., Hjetland, H., \& Lyster, S.-A. H. (2016). Lexical Quality Matters: Effects of Word Knowledge Instruction on the Language and Literacy Skills of Third- and Fourth-Grade Poor Readers. Reading Research Quarterly, 51(2), 165-180. doi: https://doi.org/10.1002/rrq.128

Brown, A. L. (1980). Metacognitive development and reading. In R. J. Spiro, B. Bruce, \& W. Brewer (Eds.), Theoretical issues in reading comprehension (pp. 453-482). Hillsdale, NJ: Lawrence Erlbaum Associates.

Cain, K. (2007). Syntactic awareness and reading ability: Is there any evidence for a special relationship? Applied Psycholinguistics, 28, 679-694.

Cameron, L. (2001). Teaching languages to young learners. Cambridge: Cambridge University Press.

Campon, F. (2013). Library lending figures: Three cheers for children's books. The Telegraph $8^{\text {th }}$ February 2013. www.telegraph.co.uk/culture/books/booknews/9855946/Librarylending-figures-Three-cheers-for-childrens-books-but-where-is-JK-Rowling.html

Carlisle, J. (2000). Awareness of the structure and meaning of morphologically complex words: impact on reading. Reading and Writing, 12, 169-190. 
Carlisle, J. (2003). Morphology matters in learning to read: a commentary. Reading Psychology, 24, 291-322.

Carlisle, J., \& Goodwin, A. (2013). Morphemes matter: how morphological knowledge contributes to reading and writing. In C. A. Stone, E. R. Silliman, B. J. Ehren, \& G. P. Wallach (Eds.), Handbook of Language and Literacy. Development and disorders $\left[2^{\text {nd }}\right.$ Edition] (pp. 265-282). New York: Guilford Publishing House.

Carver, R. (2003). The highly lawful relationships among pseudo-word decoding, word identification, spelling, listening, and reading. Scientific Studies of Reading, 7, 127-154.

Chambers, A. (2011). Tell me: children, reading and talk with the reading environment. Gloucester: The Thimble press.

Chilton, M. (2012). Roald Dahl voted teachers' favourite author. The Telegraph $12^{\text {th }}$ March 2012. http://www.telegraph.co.uk/culture/books/booknews/9137785/Roald-Dahl-votedteachers-favourite-author.html

Clark, C., \& Rumbold, K. (2006). Reading for Pleasure: Aa research overview. The National Literacy Trust. https://files.eric.ed.gov/fulltext/ED496343.pdf

Cromley, J. G., \& Azevedo, R. (2007). Testing and refining the direct and inferential mediation model of reading comprehension. Journal of Educational Psychology, 99, 311325. doi: https://doi.org/10.1037/0022-0663.99.2.311

Cunningham, A. J., \& Carroll, J. M. (2013). Early predictors of phonological and morphological awareness and the link with reading: evidence from children with different patterns of early deficit. Applied Psycholinguistics, 36(3), 509-531. doi: https://doi.org/10.1017/S0142716413000295

Cunningham, A., Perry, K., \& Stanovich, K. (2001). Converging evidence for the concept of orthographic processing. Reading and Writing, 14, 549-468.

Dahl, R. (1982[20136]). The BFG. Book and CD read by David Walliams. London: Puffin books.

Deacon, S., \& Kirby, J. (2004). Morphological awareness: just more phonological? The roles of morphological and phonological awareness in reading development. Applied Psycholinguistics, 25, 223-238.

DeVries, B. A. (2015). Literacy assessment and intervention for classroom teachers $\left[4^{\text {th }}\right.$ edition]. Scottsdale, AZ: Holcomb Hathaway.

Drew, I. (2017). Reading in the second language classroom - consideration of the potential of $1^{\text {st }}$ language approaches in $2^{\text {nd }}$ language contexts. Paper presented at Ostfold University College, Halden $7^{\text {th }}$ March 2017.

Elbro, C. (1996). Early linguistic abilities and reading development: A review and a hypothesis about distinctness of phonological representations. Reading and Writing. An Interdisciplinary Journal, 8, 453-485.

Ericsson, K. A., \& Simon, H. A. (1993). Protocol analysis: verbal reports as data [revised edition]. Cambridge MA: Bradford.

Flavell, J. H. (1979). Metacognition and cognitive monitoring. A new area of cognitive development inquiry. American Psychologist, 34(10), 906-911.

Ginsberg, D., Honda, M., \& O’Neil, W. (2011). Looking beyond English: Linguistic inquiry for English language learners. Language and Linguistics Compass, 5(5), 249-264.

Gough, P. B., \& Tunmer, W. E. (1986). Decoding, reading and reading disability. Remedial and Special Education, 7, 6-10.

Gough, P. B., Hoover, W. A., \& Peterson, C. L. (1996). Some observations on a simple view of reading. In C. Cornoldi \& J. Oakhill (Eds.), Reading comprehension difficulties: Processes and Intervention (pp. 1-13). Mahwah, NJ: Lawrence Erlbaum.

Grabe, W. (2009). Reading in a second language: Moving from theory into practice. Cambridge: Cambridge University Press. 
Hall, C., \& Coles, M. (1999). Children's reading choices. London: Routledge.

Hogan, M. J., Dwyer, C. P., Harney, O. M., Noone, C., \& Conway, R. J. (2015). Metacognitive skill development and applied systems science: A framework of metacognitive skills, self-regulatory functions and real-world applications. In A. Peña-Ayala (Ed.), Metacognition: Fundaments, Applications, and Trends (pp. 75-106). Intelligent Systems Reference Library, vol 76. Springer, Cham. doi: https://doi.org/10.1007/978-3-319$\underline{11062-2 \_4}$

Høien, T., \& Lundberg, I. (2000). Dyslexia: From theory to intervention. Dordrecht: Kluwer Academic Publishers.

Høien-Tengesdal, I. (2010). Is the simple view of reading too simple? Scandinavian Journal of Educational Research, 54, 451-469.

Holden, J. (2004). Creative Reading. London: Demos.

Hoover, W. A., \& Gough, P. B. (1990). The simple view of reading. Reading and Writing, 2, 127-160.

Ingemansson, M. (2017). Teaching reading at primary school. Paper presented at Ostfold University College, Halden, $7^{\text {th }}$ March 2017.

Joshi, R. M., \& Aaron, P. G. (2000). The component model of reading: Simple view of reading made a little more complex. Reading Psychology, 21, 85-97.

Kirby, J. R., Deacon, S. H., Bowers, P. N., Izenberg, L., Wade-Woolley, L., \& Parrila, R. (2012). Children's morphological awareness and reading ability. Reading and Writing, 25(2), 389-410. doi: https://doi.org/10.1007/s11145-010-9276-5

Koda, K. (2007). Reading and language learning: cross-linguistic constraints on second language reading development. In K. Koda (Ed.), Reading and language learning: Special issue of language learning supplement, 57(s1), 1-44. doi: https://doi.org/10.1111/0023-8333.101997010-i1

Koda, K. (2008). Looking back and thinking forward. In K. Koda \& A. Zehler (Eds.), Learning to read across languages (pp. 1-44). New York: Routledge.

Kuhn, D., \& Dean, D. (2004). A bridge between cognitive psychology and educational practice. Theory into Practice, 43(4), 268-273.

Kuo, L.-J., \& Anderson, R. C. (2006). Morphological awareness and learning to read: A cross-language perspective. Educational Psychologist, 41(3), 161-180.

Kuo, L-J. \& Anderson, R. (2008). Conceptual and methodological issues in comparing metalinguistic awareness across languages. In K. Koda \& A. Zehler (Eds.), Learning to read across languages (pp. 36-67). New York: Routledge.

Lai, E. R. (2011). Metacognition: A literature review. Pearson research report. http://images.pearsonassessments.com/images/tmrs/Metacognition_Literature_Review_Fi nal.pdf

Laufer, B. (1997). The lexical plight in second language reading: words you don’t know, words you think you know, and words you can’t guess. In J. Coady \& T. Huckin (Eds.), Second Language Vocabulary Acquisition (pp. 20-34). New York: Cambridge University Press.

Lee, S. (2011). The relationship between morphological awareness and literacy outcomes of elementary students: A meta-analysis study. PhD Dissertation, University of Oregon.

Lundberg, I. (2002). The child's route into reading and what can go wrong. Dyslexia, 8(1), 113. doi: https://doi.org/10.1002/dys.204

Lundberg, I. (2009). Early precursors and enabling skills of reading acquisition. Scandinavian Journal of Psychology, 50(6), 611-616. doi: https://doi.org/10.1111/j.14679450.2009.00778.x 
Lyster, S.-A. H., Lervåg, A. O., \& Hulme, C. (2016). Preschool morphological training produces long-term improvements in reading comprehension. Reading and Writing, 29, 1269-1288. doi: https://doi.org/10.1007/s11145-016-9636-x

Magliano, J. P., \& Millis, K. K. (2011). Assessing comprehension during reading with the reading strategy assessment tool (RSAT). Metacognition and learning, 6(2), 13l-154. doi: https://doi.org/10.1007/s11409-010-9064-2

Malcolm, N. (1997). The Origins of English Nonsense. London: Fontana/HarperCollins.

Martinez, M. E. (2006). What is metacognition? Phi Delta Kappan, 87(9), 696-699.

Nagy, W. (2007). Metalinguistic awareness and the vocabulary-comprehension connection. In R. Wagner, A. Muse, \& K. Tannenbaum (Eds.), Vocabulary Acquisition: implications for reading comprehension (pp. 52-77). New York: Guilford.

Nagy, W., Berninger, V., \& Abbott, R. (2006). Contributions of morphology beyond phonology to literacy outcomes of upper elementary and middle school students. Journal of Educational Psychology, 98(1), 134-147.

Naylor, A., \& Wood, A. B. (2012). Teaching Poetry: reading and responding to poetry in the secondary classroom. London: Routledge.

Nunes, T., \& Bryant, P. (2007). Improving Literacy by Teaching Morphemes. London: Routledge.

Nunes, T., Bryant, P., \& Bindman, M. (2006). The effects of learning to spell on children's awareness of morphology. Reading and Writing, 19(7), 767-787. doi: http://dx.doi.org/10.1007/s11145-006-9025-y

O’Malley, J. M., \& Chamot, A. U. (1990). Learning Strategies in Second Language Acquisition. New York: Cambridge University Press.

Oxford English Dictionary. www.oed.com

Oxford, R. L. (1993). Research on second language learning strategies. Annual Review of Applied Linguistics, 13, 175-187. doi: https://doi.org/10.1017/S0267190500002452

Paris, S. G., Wasik, B.A., \& Turner, J. C. (1991). The development of strategic readers. In R. Barr, M. L. Kamil, P. B. Mosenthal, \& P. D. Pearson (Eds.), Handbook of reading research, Volume II (pp. 609-640). New York: Longman.

Perfetti, C. (1994). Psycholinguistic and reading ability. In M. A. Gernsbacher (Ed.), Handbook of Psycholinguistics (pp. 849-894). San Diego: Academic Press.

Perfetti, C. (1999). Comprehending written language: a blueprint for the reader. In C. Brown \& P. Hagoort (Eds.), Neurocognition of language (pp. 167-208). Oxford: Oxford University Press.

Perfetti, C. (2007). Reading ability: lexical quality to comprehension. Scientific studies of Reading, 11(4), 357-383.

Perfetti, C. A., \& Hart, L. (2002). The lexical quality hypothesis. In L. Verhoeven, C. Elbro, \& P. Reitsma (Eds.), Precursors of functional literacy (pp. 67-86). Amsterdam: John Benjamins.

Perfetti, C. A., Landi, N., \& Oakhill, J. (2005). The acquisition of reading comprehension skill. In M. J. Snowling \& C. Hulme (Eds.), The science of reading: A handbook (pp. 227-247). Oxford: Blackwell.

Perfetti, C., \& Hart, I. (2001). The lexical basis of comprehension skill. In D. Gorfien (Ed.), On the consequences of meaning selection (pp. 67-86). Washington DC: American Psychological Association.

Perfetti, C., \& Stafura, J. (2014). Word Knowledge in a theory of reading comprehension. Scientific studies of Reading, 18(1), 22-37. doi: https://doi.org/10.1080/10888438.2013.827687 
Pressley, M. (2002). Metacognition and self-regulated instruction. In A. Farstrup \& S. Samuels (Eds.), What research has to say about reading instruction [ $3^{\text {rd }}$ edition] (pp. 291-309). Newark, DE: International Reading Association.

Pressley, M., \& Afflerbach, P. (1995). Verbal protocols of reading: the nature of constructively responsive reading. Hilsdale, NJ: Erlbaum.

Pressley, M., \& Gaskins, I. W. (2006). Metacognitively competent reading comprehension is constructively responsive reading: how can such reading be developed in students? Metacognition and Learning, 1(1), 99-113. doi: https://doi.org/10.1007/s11409-006-7263-7

Quigley, A. (2018). Closing the vocabulary gap. London: Routledge.

Ramirez, G., Chen, X., Geva, E., \& Kiefer, H. (2010). Morphological awareness in Spanishspeaking English language learners: Within and cross-language effects on word reading. Reading and Writing, 23(3-4), 337-358.

Redman, S. (1997). English vocabulary in use. Cambridge: Cambridge University Press.

Schmitt, N. (2000). Vocabulary in language teaching. Cambridge: Cambridge University Press.

Schraw, G., Crippen, K. J., \& Hartley, K. (2006). Promoting self-regulation in science education: Metacognition as part of a broader perspective on learning. Research in Science Education, 36, 111-139.

Singson, M., Mahony, D., \& Mann, V. (2000). The relation between reading ability and morphological skills: evidence from derivational suffixes. Reading and Writing, 12(3), 219-252. doi: https://doi.org/10.1023/A:1008196330239

Skaftun, A. (2011). Understanding reading development: a phenomenological perspective. L1-educational studies in language and literature, 11, 127-148.

Stafura, J. Z., \& Perfetti, C. A. (2017). Integrating word processing with text comprehension: Theoretical frameworks and empirical examples. In K. Cain, D. L. Compton, \& R. K. Parrila (Eds.), Theories of Reading Development (pp. 9-32). doi: https://doi.org/10.1075/swll.15.02sta

Stewart, S. (1979). Nonsense: Aspects of intertextuality in folklore and literature. Baltimore: Johns Hopkins University Press.

Tarrant, P. \& Holt, D. (2016). Metacognition in the primary classroom. London: Routledge.

The BFG Lesson Plans (2018). http://www.roalddahl.com/create-and-learn/teach/teach-thestories/the-bfg-lesson-plans

The BFG Phizzwizzing Lesson Plans (2017). http://www.roalddahl.com/docs/BFGlessonplans_web_1467018727.pdf

Thornbury, S. (2002). How to teach vocabulary. London: Longman.

Tigges, W. (1988). An anatomy of literary nonsense. Amsterdam: Rodopi.

Tong, X. L., Deacon, S. H., Kirby, J. R., Cain, K., \& Parrila, R. (2011). Morphological Awareness: A Key to Understanding Poor Reading Comprehension in English. Journal of Educational Psychology, 103, 523-534.

Topping, K. J. (2010). What kids are reading 2010. The book-reading habits of students in British schools. London: Renaissance Learning UK.

Topping, K. J. (2017). What kids are reading 2017. The book-reading habits of students in British schools. London: Renaissance Learning UK. http://whatkidsarereading.co.uk/

Tunmer, M., Herriman, M., \& Nesdale, A. (1988). Metalinguistic abilities and beginning reading. Reading Research Quarterly, 23, 134-158.

Tunmer, W., Pratt, C., \& Herriman, M. (1984). Metalinguistic awareness in children. Berlin: Springer Verlag.

UK Department for Education (2012). Research Evidence on Reading for Pleasure. https://www.gov.uk/government/uploads/system/uploads/attachment_data/file/284286/rea ding_for_pleasure.pdf 
Using the BFG in the Classroom (2017).

http://www.roalddahl.com/docs/BFG_EducatorsGuide_1478879891.pdf

Vellutino, F. R., Fletcher, J. M., Snowling, M. J., \& Scanlon, D. M. (2004). Special reading disability (dyslexia): What have we learned in the past four decades? Journal of Child Psychology and Psychiatry, 45, 2-40.

Verhoeven, L. (2000). Components of early second language reading and spelling. Scientific Studies of Reading, 4, 313-330.

Verhoeven, L., \& Perfetti, C. A.(2011). Morphological processing in reading acquisition: A cross-linguistic perspective. Applied Psycholinguistics, 32(3), 457-466. doi: https://doi.org/10.1017/S0142716411000154

Verhoeven, L., \& Snow, C. E. (2001). Literacy and motivation: Bridging cognitive and sociocultural viewpoints. In L. Verhoeven \& C. Snow (Eds.), Literacy and motivation: Reading engagement in individuals and groups (pp. 1-20). Mahwah, NJ: Lawrence Erlbaum Associates.

Wagner, R., Muse, A., \& Tannenbaum, K. (2007). Promising avenues for better understanding implications of vocabulary development for reading comprehension. In R. Wagner, A. Muse, \& K. Tannenbaum (Eds.), Vocabulary acquisition: Implications for reading comprehension (pp. 276-291). New York: Guilford.

Williams, J., \& Atkins, J. (2009). The role of metacognition in teaching reading comprehension to primary students. In D. J. Hacker, J. Dunlosky, \& A. C. Graesser (Eds.), The Handbook of Metacognition in Education (pp. 26-43). Routledge Handbooks Online: https://www.routledgehandbooks.com/doi/10.4324/9780203876428.ch3

Wilson, D., \& Conyers, M. (2016). Teaching students to drive their brains. Alexandria, US: ASCD publishers.

Yuill, N. (1996). A funny thing happened on the way to the classroom: jokes, riddles and metalinguistic awareness in understanding and improving poor comprehension in children. In C. Cornoldi \& J. Oakhill (Eds.), Reading comprehension difficulties (pp. 193220). Mahwah, NJ: Erlbaum.

Zipke, M. (2007). The role of metalinguistic awareness in the reading comprehension of sixth and seventh graders. Reading Psychology, 28(4), 375-396.

Zipke, M. (2011). First graders receive instruction in homonym detection and meaning articulation: The effect of explicit metalinguistic awareness practice on beginning readers. Reading Psychology, 32(4), 349-371.

Zipke, M., Ehri, L. E., \& Cairns, H. (2009). Using semantic ambiguity instruction to improve third graders' metalinguistic awareness and reading comprehension: An experimental study. Reading Research Quarterly, 44(3), 300-321. 